\title{
Margaret McCartney: Don’t be bullied into prescribing Tamiflu
}

\author{
Margaret McCartney general practitioner, Glasgow
}

I have recurrent thoughts about times when doctors felt adamant about the benefit of interventions-putting babies to sleep on their front, for example, or giving steroids to people with head injury, or bloodletting - that turned out to be lethal.

Now we have guidelines, hundreds of them. Good guidelines would distil evidence cautiously, making clear what we know and where the gaps are. They would say how many people would get what benefit from a treatment, while identifying the cost in terms of harm. But guidelines are not always applicable to our patients, ${ }^{1}$ and they are meant to guide practice; rarely should they dictate it.

The medical director and the centre director for the Thames Valley area of NHS England have recently written to GPs about the prophylactic use of oseltamivir (Tamiflu) for flu in nursing homes. They wrote, "It is concerning that doctors may be deterred from prescribing antivirals and this could be putting lives at risk."

They noted "differing interpretations of the evidence base" but added that the Medical Defence Union has identified an "expectation on the part of the public and the legal profession that NICE [National Institute for Health and Care Excellence] guidance and PHE [Public Health England] advice would be followed." They also said "it is expected" that GPs "would make a decision to prescribe based on the needs of their patient and the evidence of best practice and guidance from national bodies such as NICE and PHE," adding, "There is also an expectation defined in the GMC's [General Medical Council] Good Medical Practice that a doctor will respond to an organisation advising on public health."

This reads as a veiled threat: if GPs decide not to prescribe oseltamivir for all patients in a nursing home, lawyers and the GMC could dust down their robes and eviscerate the doctor for not following orders. In a no blame, patient centred NHS, things might be different.

Why might doctors hesitate with their prescription pads? It could be because 33 people have to be treated prophylactically to prevent one case of flu. ${ }^{2}$ One in 20 will vomit, and one in 100 will have neuropsychiatric side effects. Or maybe it's because NICE didn't include a negative trial in its calculations. ${ }^{3}$ And
PHE cites serial relative risks, but it remains unclear whether the data apply to multimorbid people in nursing homes. ${ }^{4}$

All of this leaves us with a drug of uncertain, probably marginal benefit—and difficult choices. The architects of mass public health interventions still don't grasp that populations are made up of individual patients. Each person offered antivirals needs not just an assessment of dose but also a discussion of risk and harm. Without extra resources what work would PHE suggest that primary care staff stop doing to fit this in?

Doctors must question what they are told to do, speak up, and point out flaws in arguments when asked to prescribe drugs of questionable benefit. Prescribing because of fear is toxic to patient care and safety.

Competing interests: I have read and understood the BMJ policy on declaration of interests and declare the following interests: I'm an NHS GP partner, with income partly dependent on Quality and Outcomes Framework points. I'm a part time undergraduate tutor at the University of Glasgow. I've written two books and earn from broadcast and written freelance journalism. I'm an unpaid patron of Healthwatch. I make a monthly donation to Keep Our NHS Public. I'm a member of Medact. I'm occasionally paid for time, travel, and accommodation to give talks or have locum fees paid to allow me to give talks but never for any drug or public relations company. I was elected to the national council of the Royal College of General Practitioners in 2013 and am chair of its standing group on overdiagnosis. I have invested a small amount of money in a social enterprise, Who Made Your Pants?

thebmj.com Blog: The BMJ Today: Should I prescribe anti-virals to prevent flu for nursing home patients? (http://blogs.bmj.com/bmj/2015/ 01/21/the-bmj-today-should-i-prescribe-anti-virals-to-prevent-flu-fornursing-home-patients/)

The BMJs readers can buy Margaret's new book, Living with Dying, for $£ 7.99$ (RRP £11.99) including UK delivery from www.pinterandmartin. com with checkout code BMJ799.

Provenance and peer review: Commissioned; not externally peer reviewed.

Steel N, Abdelhamid A, Stokes T, Edwards H, Fleetcroft R, Howe A, et al. A review of clinical practice guidelines found that they were often based on evidence of uncertain relevance to primary care patients. J Clin Epidemiol 2014; published online 5 Sept; doi:10. 1016/j.jclinepi.2014.05.020 
2 Jefferson T, Jones M, Doshi P, Spencer EA, Onakpoya I, Heneghan C. Oseltamivir for influenza in adults and children: systematic review of clinical study reports and summary of regulatory comments. BMJ 2014;348:g2545.

3 Cohen D. GPs are told to treat with scepticism advice on anti-flu drugs from Public Health England. BMJ 2015;350:h258.
4 Phin N, Moll R. GPs are told to treat with scepticism advice on anti-flu drugs from Public Health England. BMJ Rapid response 16 Jan 2015. www.bmj.com/content/350/bmj.h258/ rapid-responses.

Cite this as: BMJ 2015;350:h417

(c) BMJ Publishing Group Ltd 2015 